\title{
The mechanism of legal regulation of innovative technologies in the agro-industrial complex of the Eurasian Economic Union: realities and prospects
}

\author{
Veronika Meshcheryagina ${ }^{1,}{ }^{,}$, Maria Vilacheva ${ }^{1}$, Alexander Kurdyumov $^{1}$, Madina \\ Kyarova $^{2}$, and Svetlana Temmoeva ${ }^{2}$ \\ ${ }^{1}$ Ural State University of Economics, Yekaterinburg, Russia \\ ${ }^{2}$ Kabardino-Balkarian State Agricultural University named after V.M. Kokova, Lenin Avenue, 1V, \\ 360030 Nalchik, Russia
}

\begin{abstract}
The article contains a research of the elements of the legal mechanism for regulating public relations in the field of digitalization of the agro-industrial complex of the EAEU, highlights the legal means of integrating the norms of international and domestic law (using the example of the Russian Federation) in the mechanism of regulation of the agroindustrial complex of the EAEU. It is concluded that in the process of implementing the EAEU norms into the domestic legislation of Russia, there is a combination of two independent legal systems, respectively. The elements of the mechanism for the implementation of EAEU norms include transformation (inclusion of international norms in national legislation in amended form) and incorporation (exact textual reproduction of international norms in national legislation), which must be taken into account when regulating the digitalization of the agro-industrial complex. After analyzing the current regulatory framework for regulating innovative technologies in the agro-industrial complex of the EAEU, the authors have to admit its compressed volume and low elaboration from the standpoint of legal technology, as well as propose priority areas for legal regulation of innovative technologies in the agro-industrial complex of the EAEU.
\end{abstract}

\section{Introduction}

The processes of digitalization of the agro-industrial complex of the Eurasian Economic Union play a leading role in building modern economic integration of its member countries, in accordance with the Agricultural Development Strategy approved by the Eurasian Economic Commission, where it is indicated, that innovative approaches should become the basis for the further development of food security in the region, a more complete import substitution, the production of high-tech products, an increase in export volumes through

\footnotetext{
*Corresponding author: metsheryagina@yandex.ru
} 
the use of IT technologies, information databases, smart contacts of states and business entities, etc. [1].

The objectives of the agreed agro-industrial policy set out in the Treaty on the EAEU presuppose the use of mechanisms of interstate interaction, among them are: forecasting in the agro-industrial complex; regulation of the common agricultural market; development of uniform requirements in the field of production and circulation of products; integrated information support of the agro-industrial complex.

Of course, these processes cannot take place without the development of international legal norms - the main regulator of public relations, which should subsequently be introduced into the domestic legislation of the EAEU member states. In legal science, such "introduction" occurs through the implementation procedure - a complex legal phenomenon, which is a set of legal forms and methods of adapting an international norm to domestic legislation.

In this context, it should be noted that the introduction of innovative technologies is of an advanced nature and is not always subject to proper legal regulation, which complicates the implementation processes. The Treaty on the EAEU, which entered into force for the Russian Federation on January 1, 2015, specifically stipulates that the task of harmonizing the legislation of the member states is to establish similar (comparable) rules of legal regulation of the common financial market, provided that the remaining differences will not hinder effective functioning of the common financial market.

The development of bilateral and multilateral economic relations of the Russian Federation, mutually beneficial and equal partnership with foreign states based on respect for the principles of independence and sovereignty, pragmatism, and upholding national priorities are the priority tasks of the foreign policy of the Russian Federation [2]. In this regard, it is very important to pay attention to the theory and practice of the international law impact on the spheres of domestic governance, including the agro-industrial sector of the economy.

This fact leads to the need to conduct research of the existing legal mechanism for regulating public relations in the field of digitalization of the EAEU agro-industrial complex. At the same time, the mechanism of legal regulation will be understood as a set of special legal means, with the help of which the regulation of social relations is performed. Legal means act as tools used in the process of legal regulation [3], they include: norms and principles of law, law enforcement acts, contracts, legal facts, subjective rights, legal obligations, prohibitions, benefits, incentives, penalties, acts of realization of rights and obligations [4].

The goal of the research is to identify the elements of the legal mechanism for regulating public relations in the field of digitalization of the EAEU agro-industrial complex, legal means and ways of interaction between elements.

To achieve this goal, it is necessary to implement the following range of tasks:

- to identify the features of the mechanism of legal regulation of public relations in the field of the agro-industrial complex, inherent to a regional international organization;

- to determine the means of integrating the norms of international and domestic law (using the example of the Russian Federation) in the mechanism of regulation of the agroindustrial complex of the EAEU;

- identify priority areas for improving the mechanism for regulating public relations in the field of digitalization of the EAEU agro-industrial complex.

\section{Materials and Methods}

To achieve this goal, it is necessary to use both general scientific research methods: analysis, synthesis, deduction and induction, abstraction, structural and functional method, 
and special methods of jurisprudence and other branches of knowledge: formal legal method, methods of legal design and technical and legal analysis, formal-logical, systemic, statistical methods, etc.

The above mentioned methodological framework will allow us to identify the mechanism of legal regulation of the EAEU agro-industrial complex from the standpoint of the norms of international and domestic law of Russia. Based on the formal legal method, the international norms contained in the acts of the EAEU bodies will be analyzed (international treaties concluded within the EAEU; decisions of the EAEU Interstate Council; decisions of the EAEU Parliamentary Assembly; decisions of the EAEU Commission), judicial practice of the EAEU court and courts of the Russian Federation constituting empirical research base.

\section{Results and Discussion}

\subsection{Features of the mechanism of legal regulation of public relations in the field of the agro-industrial complex, inherent in a regional international organization}

Determining the features of the mechanism of legal regulation of any social relations, we inevitably come across the issue of building a system of legislation containing all the necessary legal instruments. However, the complexity of building an appropriate system of legislation within this research is due to the fact that the EAEU does not belong to "classical" international organizations, since it has formed public authorities that are authorized to extend power to private entities; establishes a hierarchy of legal norms within the organization, regulates the procedure for bringing the norms of domestic law to the norms formed by an international organization.

This feature of the EAEU legal system was stated by the EAEU Court in its Decree dated April 08, 2016 in case No. CE-1-2/3-16-KC [5], noting the presence in Art. 6 of the Treaty on the EAEU, a list of sources of EAEU law, which, nevertheless, is not exhaustive (closed), since the Vienna Convention on the Law of International Treaties does not allow limiting the range of sources of international law.

Thus, the hierarchy of the EAEU legal norms is based on the priority of the norms of the Treaty on its creation (Part 1). 3 Art. 6 of the Treaty on the EAEU), lower in legal force will be introduced international treaties within the Union; international agreements of the Union with a third party; decisions and orders of the Supreme Eurasian Economic Council, the Eurasian Intergovernmental Council and the Eurasian Economic Commission, adopted within the framework of their powers.

At the same time, a direct reference is made to the need of developing norms of intranational legislation on issues related to the Decisions of the Supreme Eurasian Economic Council and the Eurasian Intergovernmental Council.

The system of legislation of the Russian Federation in terms of regulation of the agroindustrial complex is divided into two large levels: legislative (Constitution of the Russian Federation; Laws on amendments to the constitution; Federal constitutional laws; Federal laws; Laws of the Russian Federation) and the level of by-laws (Decrees of the President of the Russian Federation; Resolutions of the Government of the Russian Federation; Orders Ministries and departments of the Russian Federation; acts of local governments, etc.).

Constitution of the Russian Federation (p. 4 Art. 15) establishes the limits of the influence of the EAEU norms on domestic legislation, based on the legal force of the acts by the formulation: "The generally accepted principles and norms of international law and international treaties of the Russian Federation are an integral part of its legal system. If an 
international treaty of the Russian Federation establishes rules other than those stipulated by law, in this case, the rules of the international treaty shall apply" For a long time, this formulation caused controversial discussions about the priority of international law over the Constitution of the Russian Federation and vice versa. Although, in our opinion, it is methodologically incorrect to pose the question from this angle, since from the standpoint of the reception of international norms, constitutional norms consolidate the mechanism of adaptation and application of an international norm, without putting an ultimatum on the supremacy of international treaties or domestic acts. It seems that it is about this property of implementation that Professor Zh.I. Ovsepyan wrote the following: "Priority of application" rather than "higher legal force" is more acceptable from the standpoint of the requirements of the principle of state sovereignty and, at the same time, respect for the requirements of the Vienna Convention on the Law of Treaties"[6].

An important role in the application of international law on the territory of the Russian Federation is played by the Constitutional Court of the Russian Federation (hereinafter referred to as the Constitutional Court of the Russian Federation), which, in accordance with paragraph 4 of Art. 3 of Federal constitutional law "Concerning the Constitutional Court of the Russian Federation" (Federal constitutional law No. 1, 1994) has the exclusive authority to interpret the norms of the Constitution of the Russian Federation.

Controversial discussions between the Constitutional Court of the Russian Federation and the EAEU court have not yet been observed, however, the preconditions for the emergence of a "conflict" in the interpretation of the EAEU norms and the subsequent execution of the EAEU court decision on the territory of the Russian Federation have already been in history. For example, in the case of exemption from payment of customs duties when importing certain categories of goods into the unified customs territory of the Customs Union, approved by the decision of the Customs Union Commission No. 728 dated July 15, 2011, when the Russian LLC "SeverAvtoProkat" applied to the Eurasian Economic Commission to challenge clause 4 of the Application Procedure, after which, to resolve the dispute, it was decided to send the case to the EurAsEC Court (the successor of which is the EAEU Court).

Disputing the decision of the Customs Union Commission, LLC "SeverAvtoProkat" referred to the peculiarities of the retroactive effect of the law, under which the conditions for the provision and use of tariff preferences in the territory of the Customs Union, determined from July 6, 2010, should no longer fall within the competence of the Customs Union Commission. From that date, such an issue, according to the applicant, could only be resolved by concluding a separate international treaty or by direct settlement in the relevant norm of the Customs Union Code.

In its decision, the EurAsEC Court indicated that due to the specifics of the sources of international law, both contractual legal norms and acts of international supranational organizations have the same legal force. The Constitutional Court of the Russian Federation did not agree with the legal positions of the Board of the EurAsEC Court on the need for identical approaches in the regulation of benefits, giving priority to the norms of the Constitution of the Russian Federation, which, guaranteeing the rights and liberties of an individual and a citizen, presupposes the existence of benefits for business and the inadmissibility of the deterioration of economic entities position in Russia under the pressure of international rights.

Proceeding to other laws regulating the agro-industrial complex, it should be noted the intersectoral nature of the object of legal regulation, inherent in civil law, constitutional law, however, the largest array of normative acts of the agro-industrial complex is concentrated in the field of public administration, that is, inherent in the branch of administrative law and, to a greater extent, by subordinate regulation [7]. 
Thus, the following features of the mechanism of legal regulation of public relations in the field of agro-industrial complex, inherent in the regional international organization of the EAEU, can be distinguished:

1) the presence of national and supranational legal systems with a specific hierarchy of legal norms;

2) the presence of national and supranational law-making and judicial bodies, the order of interaction of which is not defined at the proper level (for example, in the Russian Federation, the reference point in these issues is the Constitution of the Russian Federation and the Federal constitutional law "On the Constitutional Court of the Russian Federation");

3) a complicated procedure for integrating the EAEU legal norms into domestic legislation, the means of which - transformation and incorporation - will be described in more detail below;

4) when the terms "harmonization of legislation" and "implementation" are related, methodologically, they should be considered as a goal and a process, where the first stage of the implementation mechanism is regulatory activity of the state is aimed at concrete definition the initial norms in international agreements; the second stage - defining the concept of implementation in domestic legislation (general or special reception) in constitutional norms or norms of legislation; the third stage is the activity of the state to concrete definition the provisions of international norms into domestic legislation (transformation and incorporation). The final goal of the outlined legal mechanism is to increase the level of harmonization of the legislation of the EAEU member states.

\subsection{Means of integrating the norms of international and domestic law (on the example of the Russian Federation) in the mechanism of regulation of the agro-industrial complex of the EAEU}

In the process of implementing the EAEU norms into the domestic legislation of Russia, we are actually faced with the combination of two legal systems, respectively, the elements of the mechanism for the implementation of EAEU norms can be attributed to transformation the inclusion of international norms in national legislation in amended form; incorporation accurate textual reproduction of international norms in national legislation.

At the same time, the transformation procedure cannot be arbitrary, in view of the recognition of the norms of international law as an integral part of the Russian legal system. The subject of the transformation of international norms is set out in Art. 15 of the Federal Law "On International Treaties of the Russian Federation". To transform the EAEU norms in the field of agro-industrial complex into Russian legislation, the form of a subordinate normative legal act is most often used - Government Resolutions and orders of various ministries and departments. For example, the Decree of the Government of the Russian Federation "On the distribution of tariff quotas for meat of cattle and poultry in 2021" (No. 2142 , 2020) established the distribution of tariff quotas for 2021 in accordance with the decision of the Board of the Eurasian Economic Commission No. 102 dated August 18, 2020 in relation to meat of cattle, fresh or chilled.

Another example: the annual establishment of quotas for certain categories of goods imported into the territory of the EAEU: By the decision of the Board of the Eurasian Economic Commission No. 155 dated September 25, 2018; By the decision of the Board of the Eurasian Economic Commission No. 141 dated August 28, 2018, quotas were established for long-grain rice of Vietnam origin, placed under the release custom procedure for domestic consumption; cattle meat, etc. These norms are disclosed in the Decree of the Government of the Russian Federation No. 1495 dated December 07, 2018; Decree of the Government of the Russian Federation No. 1498 dated December 08, 2018; 
Decree of the Government of the Russian Federation 1524 dated December 14, 2018; Order of the Ministry of Economic Development of Russia No. 11 dated January 18, 2019; Order of the Ministry of Economic Development of Russia No. 9 dated January 18, 2019; Order of the Ministry of Economic Development of Russia No. 10 dated January 18, 2019).

In general, from the analysis of the legislation, it should be concluded that the form of transformation of the EAEU norms is not applied as regularly as the incorporation, about which we'll talk later.

Incorporation is applied when international norms give rise to specific legal relationships, establish general rules within the framework of which member states adapt obligations to their systems.

So, the most striking example of the incorporation of EAEU norms is the development of a standard EAEU Customs Code, formalised in the Appendix to the Treaty on the Customs Code of the Eurasian Economic Union (Signed in Moscow April 11,2017), which became a general law regulating relations in the field of movement of goods, works and services in the EAEU member states.

There are common situations in which a direct reference to the EAEU legal norms is applied in the legal documents of the customs authorities. So, in the Decision of the Council of the Eurasian Economic Commission No. 57 dated July 10, 2020 "On Amendments to the Rules for Determining the Origin of Goods Imported to the Customs Territory of the Eurasian Economic Union (Non-Preferential Rules for Determining the Origin of Goods)", the issues of VAT rates for the export of goods are regulated in detail. Namely - $0 \%$, if supporting documents are submitted to the tax authority (clause 1 of article 72 of the EAEU Treaty, clause 3 of the Protocol on the procedure for levying indirect taxes and the mechanism of control over their payment when exporting and importing goods, performing work, rendering services ( Appendix No. 18 to the Treaty on the EAEU)), which are automatically applied by the customs authorities of the Russian Federation.

Another example: the Order of the Government of the Russian Federation N 151-r dated February 02, 2015 "On Approval of the Strategy for sustainable development of rural areas of the Russian Federation for the period up to 2030" already makes a direct reference to the EAEU norms in the field of food clusters.

At the same time, it is necessary to stimulate the development of the constituent entities of the Russian Federation with favorable natural and economic conditions for conducting intensive and competitive agro-industrial production, using interregional and regional innovation and investment projects for the production of certain types of agricultural products, raw materials and food.

To do this, it is necessary to develop an all-Russian scheme for the location of agroindustrial production, on the basis of which it is advisable to define and form specialized production zones for certain types of agricultural products, introduce a management system and implement a rational intra-regional distribution of agricultural production, taking into account the possible development of food and processing industries, the creation of interstate food clusters within the framework of the Eurasian Economic Union.

It is important to note that the incorporation of EAEU norms into Russian legislation involves not only rule-making bodies, but also the judiciary. By way of illustration, one must have to indicate the Determination of the Judicial Collegium for Economic Disputes of the Supreme Court of the Russian Federation (No. 306-ES20-387 dated May 21, 2020,) in case No. A06-2706/2019 on the import of goods of required quality into the Russian Federation. 


\subsection{Priority areas for improving the mechanism for regulating public relations in the field of digitalization of the EAEU agro-industrial complex}

One of the main acts in the field of digitalization of the EAEU agro-industrial complex is the Decision of the Eurasian Intergovernmental Council No. 4 dated October 25, 2017, which approved the procedure for developing initiatives within the EAEU digital agenda, for submitting them to expert platforms. Nevertheless, what is the procedure for the operation of the sites, the format and other issues are not considered in this legal act. In fact, practice is appearing in such a way that expert platforms have turned into scientific events and symposia, and respectively, it is very difficult to analyze the proposed initiatives.

It seems that at the level of this regulatory legal act, it is worth designating expert platforms as separate sections of the Internet portal of general information resources and open data of the EAEU (https://opendata.eaeunion.org/ru-ru/Pages/thematicsection.aspx).

The EAEU Portal of General Information Resources and Open Data (hereinafter referred to as the EAEU PGIROD) today is the only integrated digital resource that allows you to receive information about electronic registers of agricultural products, structures of electronic documents and information, regulatory and reference information, information support on the implementation of interstate electronic services, etc. Given the great importance of this portal, there is no separate EAEU normative act, which would regulate in detail its status, sections, etc. There is only a small article 4.2.5.6. with the name "Requirements for the technological portal of an integrated system" in the Decision of the Board of the Eurasian Economic Commission No. 55 dated April 02, 2019 "Terms of reference for the development of an integrated information system of the Eurasian Economic Union" and the conceptual base [8], which, in addition to general requirements, does not disclose the specifics of the sections portal, and the concepts are characteristic only for the customs segment, beyond which the Portal has already gone.

Nevertheless, a positive practice would be the introduction of personalized user registration with the formation of a personal account, after which business entities could post their own initiatives in a separate section, publicly discuss and vote on the need for adoption.

Specifically, the digitalization of the agro-industrial complex is mentioned in the Decision of the Council of the Eurasian Economic Commission No. 2 dated February 04, 2015 "List of indicative indexes of the development of the agro-industrial complex of the member states of the Eurasian Economic Union", which indicates the list of domestic information resources of the agro-industrial complex (a unified register of varieties of agricultural plants, general information resource of data forecast indicators of the agroindustrial complex of the Member States; a resource of data on the prices of agricultural products and food products produced in the Member States, etc.), which will be posted in an automated form on the EAEU PGIROD after that.

In addition, an information and analytical subsystem of the integrated system is being installed, which should ensure the collection, processing and storage of the following information: on the economic and production indicators of agriculture; on the volume of trade in food products and agricultural raw materials; on average selling prices, average consumer prices and average contract prices for the main types of agricultural products, food and processing industry products and food products, etc.

However, in practice, this is not implemented, since within the framework of the EAEU PGIROD Portal in the "Agro-Industrial Complex" section there are only answers to frequently asked questions in the field of the agro-industrial complex; information on export support for participants in the foreign economic activity of the member states in the field of agro-industrial complex; Information on international trade rules; information on points of entry/exit based on the general list of places of the arrival of goods in the customs 
territory of the EAEU and places of departure of goods from the customs territory of the EAEU; information on the websites of trade missions of the EAEU member states in third countries.

Obviously, this situation cannot be recognized as admissible and a detailed legal study of the provisions specified in the Decision of the EEC Council No. 2 at the level of the legislation of the Russian Federation is required.

It also seems necessary to integrate into the EAEU PGIROD a link to the Information and analytical system for operational monitoring and assessment of the state and risks of scientific and technical support for the development of agriculture, which was developed on the basis of the Decree of the Government of the Russian Federation No. 996 dated August 25, 2017 "On the approval of the Federal Scientific and Technical Program for the Development of Agriculture for 2017-2025" and provides a wide range of opportunities to analyze the information infrastructure of the expert community in the field of assessing the state and risks of scientific and technological development of agriculture, assessing the intermediate and final results of its implementation.

With regard to the development of new software, today a legal base has been formed, which indicates mathematical formulas and calculation algorithms, which should be converted into electronic form for the convenience of calculations by the subjects of the agro-industrial complex. It would be possible to place these software products in the public domain on the EAEU PGIROD. For example, the relevant calculation methods are in the Recommendation of the Board of the Eurasian Economic Commission No. 11 dated April 24, 2017 "On the Methodology for assessing the effectiveness of measures of state regulation of the agri-food market and support of the agro-industrial complex" when assessing the effectiveness of measures of state regulation of the agri-food market and state support for agriculture. The methodology makes it possible to determine which criterion (indicator, goal) led to a change in the assessment of the effectiveness of government regulation measures, which, in turn, makes it possible to develop recommendations to improve the effectiveness of government regulation measures.

Similar mathematical calculation algorithms are also available in the domestic legislation of the Russian Federation [9], and can be quite successfully implemented in the form of a software product on the Internet portals of the information retrieval system "Export opportunities of Russia" or "The Single portal of the foreign economic information of the Ministry of Economic Development of Russia. The more so because these portals have a direct reference in the regulations [10].

Another promising area of digitalization of the agro-industrial complex, which has not yet found legal consolidation in international treaties and domestic acts, is the integration of information resources between state Internet portals and private business entities introducing new technologies in the production process.

Among them, information from large enterprises that have branches in different constituent entities of Russia, which in the agricultural sector create the maximum added value in agriculture, would be especially valuable [11].

Perhaps the most susceptible to digitalization processes and supported by a regulatory framework are the processes of moving agricultural products across customs borders. The basic Customs Code of the EAEU [12] includes electronic optimization of customs procedures for import and export of agricultural products: remote release of goods, mandatory preliminary notification, remote payment of customs payments, electronic declaration, "single window" procedure, etc.

After analyzing the regulatory framework for regulating innovative technologies in the agro-industrial complex of the EAEU, we have to state its compressed volume and low elaboration from the standpoint of legal writing. 


\section{Conclusions}

Based on the study, it can be concluded that the legal mechanism for regulating public relations in the field of digitalization of the agro-industrial complex of the EAEU is at the junction of international and domestic law and expresses the implementation of international norms through transformation and incorporation.

The EAEU Treaty provides the formation of a single economic space within the territories of the participating countries, similar mechanisms for regulating the economy on the basis of harmonized or unified legal norms, the creation of supranational judicial and law-making bodies. This feature predetermined a special procedure for the implementation of the norms of international treaties of the EAEU, concluded both within the Union and with third countries, into the domestic legislation of the Russian Federation and their impact on the regulation of public relations in the economic sphere, through transformation (not used so regularly) and incorporation (applies in the event than international norms give rise to specific legal relations, establish general rules within the framework of which participating states adapt obligations to their systems).

Having analyzed the regulatory basis for regulating innovative technologies in the agroindustrial complex of the EAEU, we have to state its compressed volume and low elaboration from the standpoint of legal writing. In fact, the only area of digitalization of the agro-industrial complex that has due legal regulation relates to customs legislation.

The currently existing EAEU PGIROD Internet portal can become constructive information and analytical system of the EAEU in the event of additions to the acts of public supranational bodies of the EAEU. Unfortunately, now this portal does not reflect the necessary information about the agro-industrial complex of the participating countries, provided for in the Decision of the Council of the Eurasian Economic Commission No. 2 dated February 04, 2015. It also seems necessary to integrate a link to the Information and analytical system of operational monitoring into the EAEU PGIROD and assessing the state and risks of scientific and technical support of agriculture development.

A good practice would be to introduce personalized user registration with the formation of a personal account, after passing which business entities could post their own initiatives in a separate section, publicly discuss and vote on the necessity for adoption.

\section{References}

1. The food security doctrine of the Russian Federation, approved by the Decree of the President of the Russian Federation N 120 dated January 30, 2010 "On the approval of the Doctrine of food security of the Russian Federation"; The strategy for the development of the information society in the Russian Federation for 2017-2030, approved by the Decree of the President of the Russian Federation N 203 dated May 09, 2017 "On the Strategy for the Development of the Information Society in the Russian Federation for 2017-2030", etc.

2. Decree of the Government of the Russian Federation No. 717 dated July 14, 2012 "On the State Program for the Development of Agriculture and Regulation of the Markets of Agricultural Products, Raw Materials and Food"//SPS "ConsultantPlus"

3. Resolution of the Eurasian Economic Union Court dated April 08, 2016 in case No. CE-1-2/3-16-KC $<$ On termination of proceedings in the case upon the application LLC "Remdizel" Production Enterprise (Russian Federation) on recognizing an additional note to positions 8408101100 - 8408109900 ТН ВЭД ЕAEU, contained in the table of the Explanations to the unified nomenclature of goods subject to the foreign trade of the EAEU (volume 6, sections I - XXI, groups 1 - 97), annex to the 
Recommendation of the EEC Board dated 03/12/2013 N 4, contrary to Article 5 of the Treaty on the Eurasian Economic Commission dated 11/1/2011, as well as the Decision of the EEC Council dated 07/16/2012 N 54> (Together with the "dissenting opinion of judge Neshataeva T.N. (case No. CE-1-2 / 3-16-KS) ")

4. Order of the Ministry of Agriculture of Russia No. 517 dated August 28, 2020 "On approval of methods for calculating the values of certain indicators of the State Program for the development of agriculture and regulation of markets for agricultural products, raw materials and food", SPS "ConsultantPlus"

5. Order of the Government of the Russian Federation No. 1806-r dated October 18, 2010 "On Approval of the Comprehensive Program for the Participation of the Russian Federation in International Cooperation in the Field of Agriculture, Fisheries and Food Security"//SPS "ConsultantPlus"

6. Decision No. 60 of the Interstate Council of the Eurasian Economic Community "On the Concept of Establishing an Integrated information system for foreign and mutual trade of the customs union and priority measures for its implementation" (Adopted in St. Petersburg dated November 19, 2010); Agreement on the creation, functioning and development of an Integrated Information system for foreign and mutual trade of the Customs Union dated September 21 (2010)

7. Customs Code of the Eurasian Economic Union (Appendix No. 1 to the Agreement on the Customs Code of the Eurasian Economic Union), SPS "ConsultantPlus"

8. Decree of the President of the Russian Federation No. 640 (2016)

9. A. Kurdyumov, Scientific conference on New Industrialization, 81-84, 240 (2019)

10. E. Butsenko, A. Kurdyumov, A. Semin, Mathematics, 8, 1480 (2020)

11. A. Kurdyumov, E3S Web of Conferences, 176, 05028 (2020)

12. O. Kozhevnikov, Pravoprimenenie, 1(4), 5-13 (2017)

13. O. Ruzakova, E. Butsenko, A. Kurdyumov, Education excellence and innovation management through vision, 711-719 (2020)

14. A. V. Savoskin, A. V. Kurdyumov, M. A. Zadorina, O. A. Kozhevnikov, V. A. Meshcheryagina, Participation (2021)

15. A. V. Savoskin, A. V. Kurdyumov, V. A. Meshcheryagina, M. N. Vilacheva, Digitalization of the Russian economy as a national goal (2021)

16. A. D. Dusupova, International Public and Private Law, 5 (2019)

17. J. I. Ovsepyan, Lawyer-Jurist, 15, 77 (2015)

18. T. Yu. Falkina, Actual problems of history, politics and law, 6-8 (2017) 